\section{Corneal Degenerations}

Saeed Alwadani

Departmeny of Ophthalmology, King Saud University, Riyadh, Saudi Arabia

\section{Definition}

Corneal degenerations are a group of sporadic and age-related corneal conditions that are present in previously normal corneal tissue and occur most often near the limbus.

\section{Basic Characteristics}

Degenerative corneal processes are characterized by secondary changes in previously normal corneal tissue. Compared to corneal dystrophies, degenerative processes are not inherited, usually affect more than one corneal layer, and are asymmetric, unilateral, and usually peripheral. Often corneal degeneration is associated to neovascularization and inflammation.

There are many corneal degenerative conditions including Salzmann's nodular degeneration, calcific band keratopathy, lipid keratopathy, actinic keratopathy, pannus, and bullous keratopathy.

\section{Further Reading}

Eagle RC. Eye pathology: an atlas and text, 2nd edn. Wolters Kluwer, Philadelphia

Weisenthal R (2013-2014a) Section 8: external disease and cornea. In: American Academy of Ophthalmology (ed) Basic and Clinical Science Course (BCSC). American Academy of Ophthalmology, San Francisco

Weisenthal R (2013-2014b) Section 4: ophthalmic pathology and intraocular tumors. In: American Academy of Ophthalmology (ed) Basic and Clinical Science Course (BCSC). American Academy of Ophthalmology, San Francisco 